\title{
Analysis of Factors Affecting User Loyalty in an Online Discussion Forum
}

\author{
Jurnalistika Febra ARIELLA $^{1}$, Indra BUDI $^{2 *}$ and M. Lahandi BASKORO ${ }^{3}$
}

\author{
${ }^{1,2}$ Faculty of Computer Science, University of Indonesia, Jakarta, Indonesia \\ ${ }^{3}$ Faculty of Creative Industry and Telematics, Universitas Trilogi, Jakarta, Indonesia \\ *Corresponding author: indra@cs.ui.ac.id
}

\begin{abstract}
PT XYZ is an internet company, providing free online discussion forum as the main service with a display of advertisements as a primary source of revenue. Users are one of the most important assets for PT XYZ. Every user who visits a discussion forum will be exposed with advertisements in the forum which will contribute to the business revenue of PT XYZ. Unfortunately, in the past six years, the number of users has been decreased by $64 \%$, which surely affecting PT XYZ's business profits. Therefore, user loyalty is a key aspect that needs to be underlined. The focus of this study is to analyze factors that affect user loyalty in the online discussion forum of PT XYZ. Factors that directly affect user loyalty consist of perceived usefulness, user attitude response, user relationship quality, and user satisfaction. While the indirect factors consist of social influence, ease of use, product design, quality of argument, the credibility of sources, information, social exchange, and recreation. This study is a quantitative research with a structural equation model (SEM) approach. The results show that user loyalty is affected by factors of relationship quality between online discussion forum PT XYZ and users, which directly affected by argument quality, and also source credibility.
\end{abstract}

Keywords: online discussion forum, user loyalty, relationship quality, argument quality, source credibility

\section{INTRODUCTION}

PT $\mathrm{XYZ}$ is an internet-based company with the main service providing free online discussion forum. This company has been established 19 years ago, encouraging user generated content which every user has freedom to write and publish their own content. The main revenue for PT XYZ is from advertisements on the discussion forum. Every user who visits discussion forum and exposed with advertisements will contribute small fraction of income for PT XYZ's business. Therefore, the discussion forum users are considered a critical asset for PT XYZ.

In the past six years, PT XYZ experienced a serious decline of active users in the discussion forum. About $64 \%$ of the users abandoned the PT XYZ discussion forum. This occurrence surely gives an impact to PT XYZ's business which has the main source of income through advertising services. Decreasing of users, means there will be less ads displayed on the discussion forum pages, which certainly then affect on the company's income.

PT XYZ expect to have an active discussion forum users. Every user who has already used discussion forum is expected to use it again in the future. This is aligned with the definition of customer loyalty, which is the strength of the relationship between individual relative attitudes and the drive to do things repeatedly [17]. The relationship is mediated by social norms and situational factors, as well as contributions from cognitive, affective, and conative reputations of relative attitudes accompanied by motivational consequences, perceptions, and behavior. So, user loyalty in discussion forums are important for PT $\mathrm{XYZ}$.

This research focuses on understanding factors that influence users of PT XYZ discussion forums. The research framework is prepared based on factors that influence user loyalty directly and indirectly. Factors that directly affect user loyalty consist of perceived usefulness [1][2], user attitude response [3], user relationship quality [4], and user satisfaction [5]. While the indirectly factors consist of social influence [1], ease of use [1][2], product design [3], quality of argument [4], credibility of sources [4], information [5], social exchange [5], and recreation [5]. Data collection is done through distributing questionnaires to discussion forum users and managed to received response from 212 respondents. Data processing is then carried out using the Structural Equation Modeling (SEM) approach using SmartPLS tools. Some test procedures used in this study are descriptive analysis, measurement models, and structural models. The research result shown that factors affecting user loyalty is relationship quality between online discussion forum and users, which directly impacted by argument quality and source credibility.

The rest of this paper is organized as follow: The introduction to the research problem is described in this section; background literatures are explained in the next section; section 3 describes methodology on how this research conducted; section 4 describes the results and analysis; and the final section outlined the conclusions.

\section{LITERATURE REVIEW}

Customer Loyalty. Customer loyalty is the strength of the relationship between individual relative attitudes and the drive to do things repeatedly. The relationship is mediated by social norms and situational factors, as well as contributions from cognitive, affective, and conative reputations of relative attitudes accompanied by motivational consequences, perceptions, and behaviors [17]. Customer loyalty also defined as a condition when a 
customer has a positive attitude towards a brand, is committed to the brand and intends to repurchase in the future [18]. Thus, it can be concluded that customer loyalty is an encouragement for individuals to do something (purchase a product) repeatedly.

Customer loyalty can be measured in several ways, namely behavior measures, measuring switch costs, measuring satisfaction, measuring brand liking, and measuring commitment [19]. Behavioral measures, measuring customer loyalty based on habitual behavior by calculating the pattern of purchases made by customers. Measuring switch costs, measuring customer loyalty based on customer loyalty to the brand. Measuring satisfaction, measuring customer loyalty based on satisfaction. Measuring liking brand, measuring customer loyalty based on his preference for brand, trust, and sense of coherence with a brand. Measuring commitment, measuring customer loyalty based on the number of interactions and commitment to the product.

Online Community. The online community is a collection of people who regularly interact with each other through the website. Online community members gather because they have the same interests or activities [20]. Community is a collection of people who interact, share, and work together to achieve the same goal. Groups that move and carry out their interactions on the Internet are online communities [21]. Online communities that gather on a website need features that support interaction with one another. Some of the supporting features needed are online identity (username, avatar, and membership level), profile page, and private message [20].

Structural Equation Modelling (SEM). Structural equation model (SEM) uses various types of models to describe the relationship between observed variables, with the same basic objective of providing quantitative tests of theoretical models hypothesized by a researcher. More specifically, various theoretical models can be tested in SEM giving a hypothesis on how the set of variables determine constructs and how these constructs are related to each other [22]. SEM combines various aspects of analysis and regression factors, so researchers can find relationships between measured and latent variables, as well as relations between latent variables [9].

There are six stages in PLS-SEM implementation, namely: (1) structural model specification; (2) measurement model specification; (3) data collection and inspection; (4) model estimation; (5) measurement model assessment; and (6) structural model assessment. Structural models or known as inner-models is the description of the relationship between latent variables. Measurement model or known as an outer-model, describes the relationship between variables with indicators. In data collection and inspection stage, researcher needs to pay attention to the existence of incomplete data, suspicious answer patterns (i.e. when all respondents' answers are answered equally), outliers or extreme responses, and data distribution that should tend to be normal. Model estimation is developed based on minimum sample size is 10 times the maximum number of arrows that point to latent variables anywhere in the PLS path model. The evaluation of the results of the reflective measurement model consists of internal consistency (composite reliability), reliability indicators, convergent validity (average variance extracted), and discriminant validity. The evaluation of the results of the formative measurement model consists of convergent validity, collinearity among indicators, significance and relevance of outer weights. Structural assessment consists of coefficients of determination $\left(\mathrm{R}^{2}\right)$, predictive relevance $\left(Q^{2}\right)$, size and significance of path coefficients, and $\mathrm{f}^{2}$ effect sizes.

\section{METHODOLOGY}

The data for this study were collected from PT XYZ forum discussion users. Data collection was conducted nonrandomly using convenience sampling technique. Convenience sampling technique selects samples based on the easiness of access from researchers to the sample [6]. The questionnaires are presented online in purpose to be accessed more easily by respondents. It uses Likert scale with a range or $1-4$ to point out user opinion with the questionnaires statement. A total number of 212 respondents were responded to the survey.

The data from collected questionnaire then processed using Structural Equation Modeling (SEM) approach. The tool that used for data processing is SmartPLS. Some test procedures used in this study are descriptive analysis, measurement models, and structural models. Descriptive analysis was conducted to get a general picture of primary data from the research conducted [7]. The measurement model is to obtain appropriateness of the model used. Measurement model will involve goodness of fit test for the outer model. This test consists of a validity test consisting of convergent validity, discriminant validity, and significance testing [8], and also reliability testing using composite reliability [9]. Structural models are carried out to see the significance of influence. The structural model will involve a goodness of fit test for the inner model. This test consists of test path significance, relevance of predictive q-square, analysis of the influence and percentage, and $\mathrm{f} 2$ effect size [8].

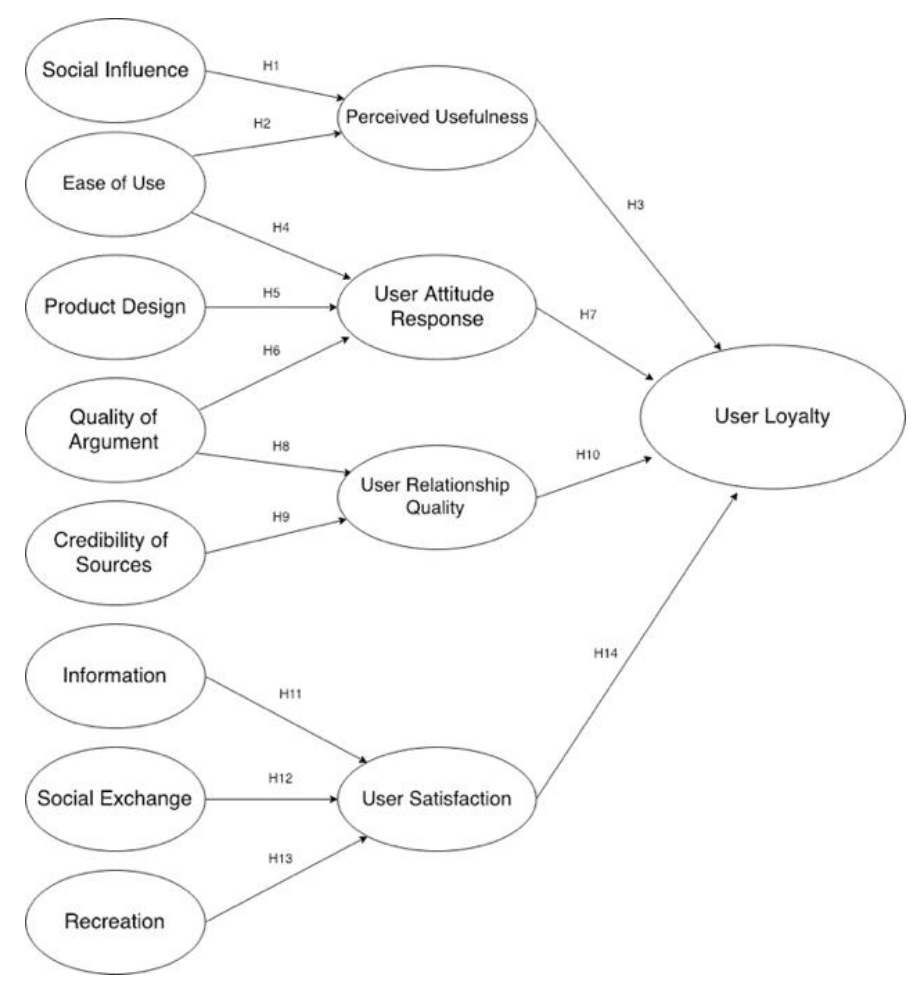

Figure 1. Research Framework 
The study was conducted to determine the factors that influence the loyalty of users of the PT XYZ discussion forum. The research framework in Figure 1 is prepared based on the factors that affect user loyalty of discussion forum directly and indirectly. Factors that influence user loyalty in discussion forums directly consist of perceived usefulness, attitude response users, user relationship quality, and user satisfaction. Meanwhile, factors that influence user loyalty indirectly consist of social influence, ease of use, product design, quality of argument, credibility of sources, information, social exchange, and recreation.

The social influence and ease of use factor predict to have a significant positive impact on user perceived usefulness which has a significant positive impact on user loyalty. Ease of use, product design, and quality of argument predict to have a significant positive impact on user attitude response which has a significant positive impact on user loyalty. Quality of argument and credibility of source predict to have a significant positive impact on user relationship quality which has a significant positive impact on user loyalty. Information, social exchange, and recreation predict to have a significant positive impact on user satisfaction which has a significant positive impact on user loyalty.

\section{RESULTS AND DISCUSSION}

Table 1. Respondent Profile

\begin{tabular}{|c|c|c|c|}
\hline Variable & Variable Detail & Total & Percentage \\
\hline \multirow[t]{2}{*}{ Gender } & Male & 142 & $67 \%$ \\
\hline & Female & 70 & $33 \%$ \\
\hline \multirow[t]{5}{*}{ Age } & $18-24$ y.o. & 77 & $36 \%$ \\
\hline & 25 - 34 y.o. & 98 & $46 \%$ \\
\hline & $35-44$ у.о. & 21 & $10 \%$ \\
\hline & 45 - 54 у.о. & 12 & $6 \%$ \\
\hline & $55-64$ y.o. & 4 & $2 \%$ \\
\hline \multirow[t]{10}{*}{ Domicile } & Jakarta & 99 & $47 \%$ \\
\hline & Bandung & 9 & $4 \%$ \\
\hline & Bekasi & 18 & $8 \%$ \\
\hline & Tangerang & 11 & $5 \%$ \\
\hline & Yogyakarta & 6 & $3 \%$ \\
\hline & Surabaya & 5 & $2 \%$ \\
\hline & Bogor & 5 & $2 \%$ \\
\hline & Depok & 7 & $3 \%$ \\
\hline & Malang & 7 & $3 \%$ \\
\hline & Others & 45 & $21 \%$ \\
\hline \multirow{5}{*}{$\begin{array}{l}\text { Long time of } \\
\text { forum usage }\end{array}$} & $1-3$ years & 51 & $24 \%$ \\
\hline & $3-5$ years & 51 & $24 \%$ \\
\hline & $5-8$ years & 53 & $25 \%$ \\
\hline & Less than 1 years & 26 & $12 \%$ \\
\hline & More than 8 years & 31 & $15 \%$ \\
\hline \multirow{2}{*}{$\begin{array}{l}\text { Frequency of } \\
\text { forum usage }\end{array}$} & Almost everyday & 89 & $42 \%$ \\
\hline & Once in a month & 23 & $11 \%$ \\
\hline
\end{tabular}




\begin{tabular}{|c|c|c|c|}
\hline & Once in a week & 41 & $19 \%$ \\
\hline & $\begin{array}{l}\text { Never accessed in the } \\
\text { last } 3 \text { months }\end{array}$ & 32 & $15 \%$ \\
\hline & $\begin{array}{l}\text { Never accessed in the } \\
\text { past year }\end{array}$ & 15 & $7 \%$ \\
\hline & Others & 12 & $6 \%$ \\
\hline \multirow{6}{*}{$\begin{array}{l}\text { Common activities } \\
\text { in forum }\end{array}$} & Read thread/post & 181 & $85 \%$ \\
\hline & $\begin{array}{l}\text { Comment in } \\
\text { thread/post }\end{array}$ & 109 & $51 \%$ \\
\hline & $\begin{array}{l}\text { Give rating in } \\
\text { thread/post }\end{array}$ & 68 & $32 \%$ \\
\hline & Subscribe thread/post & 40 & $19 \%$ \\
\hline & Create thread/post & 47 & $22 \%$ \\
\hline & Others & 13 & $6 \%$ \\
\hline
\end{tabular}

Data collection was conducted by publishing the questionnaire online. Using convenience sampling, this effort managed to collect 212 responds from PT XYZ forum discussion users. Respondent profiles are describe in Table 1. Overall, respondents profile are quite representative of user population in PT XYZ's discussion forum.

Descriptive Analysis. Descriptive analysis is calculated by finding the average of the respondent's answers on each variable. In this study, the authors used a Likert scale with a range of nominal values 1-4. Calculation of descriptive analysis interval score range (ISR) used in accordance with equation 1 is worth 0.75 .

$I S R=\frac{(\text { Max scale }- \text { Min scale })}{\text { Max scale }}$

If a variable has a very low value (interval score $1.00-$ $1.75)$, the variable is not significantly valued by the user. If a variable is of low value $(1.76-2.50)$, then the variable is judged to be poor by the user. If a variable is high value $(2.51-3.25)$, then the variable valued by the user. If a variable is intended to be very high $(3.26-4.00)$, then the variable valued very well by the user.

Based on calculation, the descriptive analysis of each variable has high value. This indicates that these variables are perceived or valued well by the user. Users get social influence from the PT XYZ discussion forum. The PT XYZ discussion forum is easy to use. The product design of PT XYZ's discussion forum is in accordance with the wishes of the users. The quality of the arguments in the PT XYZ discussion forum is good. The source of writing in the PT $\mathrm{XYZ}$ discussion forum is good. The information presented in the PT XYZ discussion forum is good. Users can feel a positive social exchange in the PT XYZ discussion forum. Users feel comfortable when using the PT XYZ discussion forum. The user feels that PT XYZ's discussion forum is useful. Users feel positive when using the PT XYZ discussion forum. Users feel that the services provided by the PT XYZ discussion forum are good so they can improve the quality of user relationships. Users of the PT $\mathrm{XYZ}$ discussion forum were satisfied with the products and services provided by the $\mathrm{PT} X Y Z$ discussion forum. Users of PT XYZ discussion forums are loyal to the PT XYZ discussion forum.

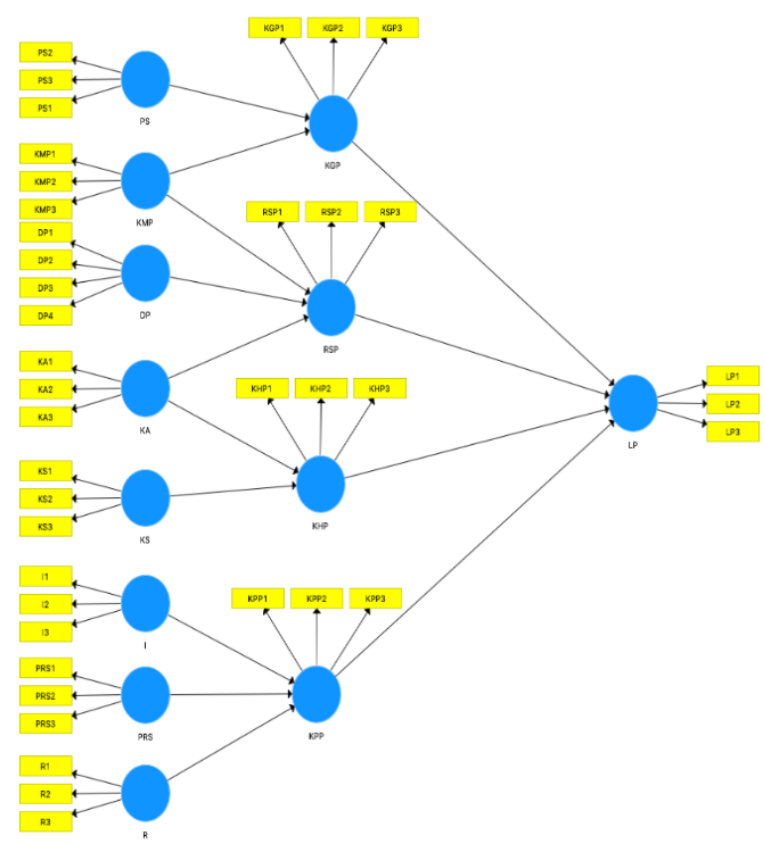

Figure 2. Initial Model

Measurement Models. The measurement model is calculated to see the appropriateness of the model used. The discussion of the measurement model will involve a goodness of fit test for the outer model. This test consists of a validity test consisting of convergent validity, discriminant validity, and significance testing [8], and reliability testing using composite reliability [9]. Variables that do not meet the validity and reliability test criteria will be discarded from the model. The initial research model is illustrated in Figure 2, with the detail code described in Table 2. 
Table 2. Variable Components

\begin{tabular}{lll}
\hline Variable Code & \multicolumn{1}{c}{ Variable } & Variable Indicators \\
\hline PS & Social Influence & PS1;PS2;PS3 \\
\hline KMP & Ease of Use & KMP1;KMP2;KMP3 \\
\hline DP & Product Design & DP1;DP2;DP3;DP4 \\
\hline KA & Quality of Argument & KA1;KA2;KA3 \\
\hline KS & Credibility of Sources & KS1;KS2;KS3 \\
\hline I & Information & I1;I2;I3 \\
\hline PRS & Social Exchange & PRS1;PRS2;PRS3 \\
\hline R & Recreation & R1;R2;R3 \\
\hline KGP & Perceived Usefulness & KGP1;KGP2;KGP3 \\
\hline RSP & Users Attitude Response & RSP1;RSP2;RSP3 \\
\hline KHP & User Relationship Quality & KHP1;KHP22;KHP3 \\
\hline KPP & User Satisfaction & KPP1;KPP2;KPP3 \\
\hline LP & User Loyalty & LP1;LP2;LP3
\end{tabular}

Convergent validity is calculated by looking at loading factors [8]. Variables defined to have good validity for construct or the value of the latent variable when the value of the loading factor is more than 0.50. Based on the calculation of loading factors using SmartPLS, the loading factor values for several indicators are less than 0.50 namely DP3, DP4, I3, KA3, KGP3, KHP2, KMP3, KPP2, KPP3, KS3, LP3, PRS3, PS2, R3, and RSP3.

The calculation of discriminant validity uses the square root of the average variant extracted [10]. In SmartPLS, the results of discriminant validity can be seen with cross loading values. Discriminant validity has a good discriminant validity if the results for each construct are all greater than the correlation with other constructs, indicating a good level of discriminant validity [3]. Based on the calculation of discriminant validity using SmartPLS, there are several indicators that smaller than the correlation of other constructs namely I3, KA3, KGP3, KMP3, KPP2, KPP3, KS3, LP3, PRS3, R3, and RSP3.

The variable significance test was conducted by calculating the bootstrap using SmartPLS [8]. Using the 95\% evidence interval, the received $\mathrm{z}$-score is 1.96 [11]. There are some variables whose values are less than 1.96 so that they are confirmed invalid. Some of these variables are KMP3, KS3, KPP3, LP3, PRS3, and RSP 3.

The indicator variables who has invalid values in the three tests, then removed from the model. The invalid indicator variables are KPP3, KMP3, KS3, LP3, PRS3, and RSP3. This testing model will then be used for reliability testing and structural model testing.

Composite reliability is a reliability test on PLS-SEM whose value is in the range $0-1$, the higher the value means that the variable also more reliable [9]. Reliability composite values $0.60-0.70$ can be accepted in exploratory research, while values between 0.70 and 0.90 can be considered satisfactory [12]. This is also in line with what [13] said that a construct variable has a good value if the reliability construct value is more than 0.70 . Based on the calculation, all variable values are reliable. The lowest composite reliability value is in the KPP variable (user satisfaction). However, because the value is yet above 0.60 , the variable is still relatively reliable. Because all variables are reliable, there are no variables removed from the model. Structural models. Structural models are carried out to see the significance of influence. The discussion of structural models will involve a goodness of fit test for the inner model. This test consists of test path significance, relevance of predictive q-square, analysis of the influence and percentage, and $\mathrm{f}^{2}$ effect size [8].

Path significance is tested by looking at the t-values in each path in the model through bootstrap calculations. With $95 \%$ confidence interval, the z-score is 1.96 . For this reason, if the $t$-value in the path is more than 1.96, the value is significant [8]. But if not, then the value is not significant. In the final model that has been carried out bootstrap calculations, there are several paths that have a t-value of less than 1.96. Path KMP $\rightarrow$ RSP, PRS $\rightarrow$ KPP, KGP $\rightarrow$ $\mathrm{LP}, \mathrm{RSP} \rightarrow \mathrm{LP}, \mathrm{KPP} \rightarrow \mathrm{LP}$ has a value of less than 1.96, while the other paths have a value of more than 1.96 or can be categorized as significant.

The path significance test results can give the following summary:

- H1: Social influence has a significant positive impact on the user perceived usefulness

- H2: The ease of use has a significant positive impact on the user perceived usefulness

- H3: The usefulness felt by users does not have a significant impact on user loyalty

- H4: The ease of use does not have a significant impact on the response of the user's attitude

- H5: Product design has a significant positive impact on the user's attitude response

- H6: The quality of arguments has a significant positive impact on the response of the user's attitude

- H7: The response of the user's attitude does not have a significant impact on user loyalty

- H8: The quality of arguments has a significant positive impact on the quality of user relationships

- H9: Source credibility has a significant positive impact on the quality of user relationships

- H10: The quality of user relationships has a significant positive impact on user loyalty

- H11: Information has a significant positive impact on user satisfaction.

- H12: Social exchange does not have a significant impact on user satisfaction. 
- H13: Recreation has a significant positive impact on user satisfaction.

- H14: User satisfaction does not have a significant impact on user loyalty.

The focus on predictive q-square relevance testing is to evaluate the predictive validity of models with PLS [14]. Predictive Q-square shows how well empirically collected data can be reconstructed with the help of models and PLS parameters [10]. This test refers to the value of the last endogenous construct variable in the model, which is the LP variable.

The negative q-square predictive value indicates that there is no predictive relevance to the model, while the predictive q-square value of more than 0 illustrates the predictive relevance of the endogenous construct model [15]. The calculation results show that the value of $\mathrm{Q}^{2}$ for the LP variable is 0.310 . This indicates that this research model has predictive relevance for constructing user loyalty models.

The magnitude of the effect to be considered is the direct effect and indirect influence of construct variables on the last endogenous variable, LP [8]. The purpose of this calculation is to see what variables have a direct influence and indirect influence on these variables. There is a direct and indirect influence on the last endogenous variable, LP. Some variables that have a direct influence on LP are KGP, RSP, KHP, and KPP. PS has an indirect influence on LP through KGP. KMP has an indirect influence on LP through KGP or RSP. The DP has an indirect influence on the LP through RSP. KA has indirect influence on LP through RSP or KHP. KS has an indirect influence on LP through KHP. I have an indirect influence on LP through KPP. PRS has an indirect influence on LP through KPP. R has indirect influence on LP through KPP.

The $\mathrm{f}^{2}$ effect size is used to measure the impact given by a variable to the last endogenous variable. $\mathrm{f}^{2}$ effect size is appropriate for calculating effect sizes in multiple regression models where interest-free variables and dependent variables are both continuous [16]. The $\mathrm{f}^{2}$ effect size has three sizes, namely small when less than 0.02 , medium when $0.03-0.15$, and large when $0.16-0.35$ [8]. KGP (perceived usefulness) has a small impact on user loyalty. KHP (quality of user relations) has a moderate impact on user loyalty. KPP (user satisfaction) has a moderate impact on user loyalty. RSP (user attitude response) has a moderate impact on user loyalty. Therefore, the KHP and RSP variables have a large effect on the loyalty of users of discussion forums.

\section{CONCLUSIONS AND RECOMMENDATIONS}

The results of data analysis show that the factors that influence user loyalty of PT XYZ discussion forum are quality of user relationships, which are supported by the quality of argument and also credibility of source. Other factors have no directly significant impact on user loyalty. Social influence and ease of use have a significant impact on perceived usefulness, but perceived usefulness has a small and not significant impact on user loyalty. Product design and argument quality have a significant impact on the user's attitude response, but it is not the case with ease of use. The response of the user's attitude has a moderate impact but is not significant to user loyalty. Information and recreation have a significant impact on user satisfaction, while social exchanges do not have a significant impact on user satisfaction. User satisfaction has a small and insignificant impact on user loyalty.

Theoretically, it is known that the factors that influence user loyalty in discussion forums are quality of user relationships that are influenced by credibility of source and quality of argument. In order to maintain user loyalty, PT XYZ needs to highlight the quality of relationship that given to the users. This can be accomplished by managing quality of arguments in discussion forum and increasing credibility of source.

Numerous research have addressed factors that affecting user loyalty, but there are no significant study specifically done in the online forum. This paper seek to contribute the novelty in that area. The findings in this study would be beneficial for futher development of the PT XYZ or other organization with similar service to improve their user loyalty. In addition, further research can examine analysis of factors that affecting PT XYZ discussion forum users to be disloyal by changing the focus of the research sample, namely those who have not used the PT XYZ discussion forum anymore. Subsequent research can also examine deeper related hidden paths that may exist within the conceptual framework of research.

\section{ACKNOWLEDGMENT}

The authors acknowledge the PIT 9 research grant NKB0010/UN2.R3.1/HKP.05.00/2019 from Directorate Research and Community Services, Universitas Indonesia.

\section{REFERENCES}

[1] Sreeram, A. Kesharwani, and S. Desai, "Factors affecting satisfaction and loyalty in online grocery shopping: an integrated model," Journal of Indian Business Research, vol. 9, no. 2, pp. 107-132, 2017.

[2] Ruiz-Mafe, J. Martí-Parreño, and S. Sanz-Blas, "Key drivers of consumer loyalty to Facebook fan pages," Online Information Review, vol. 38, no. 3, pp. 362-380, 2014.

[3] C.-L. Hsu, Y.-C. Chen, T.-N. Yang, W.-K. Lin, and Y.-H. Liu, "Does product design matter? Exploring its influences in consumers' psychological responses and brand loyalty," Information Technology \& People, vol. 31, no. 3, pp. 886-907, 2018.

[4] C.-D. Chen and E. C. Ku, "Bridging indistinct relationships and online loyalty: evidence from online interest-based communities," Online Information Review, vol. 37, no. 5, pp. 731-751, 2013.

[5] C.-P. Hsu, H.-C. Huang, C.-H. Ko, and S.-J. Wang, "Basing bloggers power on readers satisfaction and loyalty," Online Information Review, vol. 38, no. 1, pp. 78-94, 2014.

[6] G. Rawat, "Non Random Sampling Techniques" [PDF],

https://www.scribd.com/document/106655428/N on-Random-Sampling-Techniques , 17 Sept 2012, retrieved on 12 January 2019.

[7] N.A. Ghifari, "Analisa Pengaruh Customer Value Anticipation Terhadap Customer Satisfaction dan 
Customer Loyalty: Studi Kasus PT Bank Negara Indonesia", 2016

[8] Wijaya, "Contoh Analisa Cepat Analisa SEM dengan smartPLS. https://doi.org/10.13140/RG.2.1.4862.6164", 2015, retrieved on 15 November 2018

[9] J. F. Jr., G. T. Hult, C. M. Ringle, and M. Sarstedt. "A Primer On Partial Least Squares Structural Equation Modeling (PLS-SEM)". USA: SAGE Publications, 2014.

[10] Fornell, and D.F. Larcker, "Structural equation models with unobservable variables and measurement error: algebra and statistics", Journal of Marketing Research, Vol. 18 No. 3, pp. 39-51, 1981.

[11] Fariza, "Confidence Interval", http://irma.lecturer.pens.ac.id/ Statistik/Confidence\%20Interval.pdf, 2013, retrieved on 12 January 2019.

[12] J. C. Nunally and I. Bernstein, "Psychometric theory", New York: McGraw-Hill, 1994.

[13] S. H.Wijanto, "Structural Equation Modelling", Yogyakarta: Graha Ilmu, 2008

[14] S. Akter, J. D'Ambra, and P. Ray, "An evaluation of PLS based complex models: the roles of power analysis, predictive relevance and GoF index", proceedings of the 17th Americas Conference on Information Systems (AMCIS2011) (pp. 1-7), Detroit, USA: Association for Information Systems, 2011.

[15] P. Andreev, "Implementation of Partial Least Squares (PLS) Modeling in Economics and Business Management Research" [PDF], University of Ottawa, 19 August, 2013.

[16] J.E. Cohen, "Statistical Power Analysis for the Behavioral Sciences", Hillsdale, NJ: Lawrence Erlbaum Associates, Inc, 1988.

[17] A.S. Dick, and K. Basu, "JAMS", 22: 99, https://doi.org/10.1177/0092070394222001,199 4, retrieved on 22 September 2018.

[18] J. C. Mowen and M. S. Minor, "Consumer behavior”, Boston: Pearson Custom Publishing, 2004.

[19] M. Rizan, B. Saidani, dan Y. Sari, "Pengaruh Brand Image dan Brand Trust Terhadap Brand Loyalty Teh Botol Sosro", Jurnal Riset Manajemen Sains Indonesia, 2012.

[20] Buss and N. Strauss, "Online communities handbook: building your business and brand on the Web", Berkeley (CA): New Riders, 2009.

[21] $\mathrm{Ng}$, "Online Community Management for Dummies", Hoboken, NJ: Wiley, 2012

[22] R.E. Schumacker and R. G. Lomax, "A Beginner's Guide to Structural Equation Modeling”, London: Lawrence Erlbaum Associates, 2004. 